Religious Studies 42, 299-313 ㄷ 2006 Cambridge University Press

doi:10.1017/S0034412506008420 Printed in the United Kingdom

\title{
The grounds of worship
}

\author{
TIM BAYNE \\ Department of Philosophy, Macquarie University, Sydney, NSW 2109, Australia
}

\author{
YUJIN NAGASAWA \\ Department of Philosophy, University of Birmingham, Edgbaston, Birmingham, \\ B15 $2 T T$ \\ CAPPE, Australian National University, Canberra, ACT 0200, Australia
}

\begin{abstract}
Although worship has a pivotal place in religious thought and practice, philosophers of religion have had remarkably little to say about it. In this paper we examine some of the many questions surrounding the notion of worship, focusing on the claim that human beings have obligations to worship God. We explore a number of attempts to ground our supposed duty to worship God, and argue that each is problematic. We conclude by examining the implications of this result, and suggest that it might be taken to provide an argument against God's existence, since theists generally regard it is a necessary truth that we ought to worship God.
\end{abstract}

\section{Introduction}

Worship has a central place in religious thought and practice. Religious rituals are structured around the worship of God, and central theological notions - such as sin, atonement, and salvation - involve implicit reference to worship. Yet despite its pivotal role, philosophers of religion have had remarkably little to say about worship. ${ }^{1}$ This silence would not be puzzling were it not for the fact that worship is in many respects an obscure attitude. In this paper we examine a central question posed by the notion of worship, namely, on what grounds are we obliged to worship God? We explore four accounts of our obligation to worship God, and argue that each faces significant obstacles. We conclude by reflecting on the implications of this result.

\section{Four issues}

Worship raises at least four general issues. First, there is the analysis of the concept of worship. What is it to worship something? To what degree is worship a 
cognitive attitude? In what ways is it related to attitudes such as admiration, respect, and awe? Can worship be reduced to these notions, or is it sui generis? Second, what are the appropriate objects of worship? Is worship an attitude that it is permissible to adopt only with respect to God, or can the theist allow that the worship of entities other than God is permissible? A third issue is epistemological: what reasons do we have for thinking that God is worthy of worship? A fourth issue concerns the grounds of worship. What kinds of properties could make it reasonable to worship God? What kinds of properties might make it obligatory to worship God? Might worship have multiple grounds, or is there a single property in virtue of which it is reasonable and/or obligatory to worship God?

We will not attempt to address each of these four issues here. Instead, we will focus on the question of what might ground our putative obligation to worship God. But to make progress on that issue we have to say something about the other issues just mentioned - in particular, we need to say something about the nature of worship itself. We turn to that task now.

\section{The analysis of worship}

Worship is clearly a complex activity, and it would seem to resist any simple analysis. Indeed, it is not at all obvious that one can give a reductive analysis of what it is to worship something. Nonetheless, we may well be able to locate worship in its conceptual neighbourhood, drawing attention to the relationships between it and related attitudes.

As has often been noted, worship appears not to be a propositional attitude. In worshipping someone, one is not related to a content or proposition but to an intentional object (which might not exist). But despite the fact that it is not itself a propositional attitude worship seems to be intimately related to propositional attitudes. In typical instances of worship, the worshipper has certain beliefs about the object of worship. For example, worshippers typically regard the object of worship as being morally superior to themselves.

Worship also involves affective and emotional attitudes such as awe, an attitude that might be regarded as a certain type of fear. To worship something seems to involve judging that the object of worship is more powerful in some respect than oneself. It is not obvious that the power in question need be a power over oneself, but it is a power that one lacks. Also internal to the attitude of worship is reverence - a form of humility and respect. The worshipper regards the object of worship as greater, in some sense, than herself. In many religious traditions worship is also taken to involve more straightforward emotional attitudes, such as love.

In addition to its affective content, worship has, or at least can have, intimate connections with certain aesthetic attitudes. As Robert Merrihew Adams says, 
'the soul of worship is admiration'. ${ }^{2}$ Mark Wynn sounds a similar note, suggesting that 'in worship the believer relates herself to the marvel of existence, by placing herself in wonder and adoration before the one in whom all existence is contained'. 3

Another group of attitudes included within the semantic orbit of worship can be broadly classified as numinal. ${ }^{4}$ Consider the classic scriptural texts associated with worship, such as the sixth chapter of Isaiah, in which the notion of worship is related to the notions of holiness and sanctity. Arguably, to worship something in a full-blooded sense of the term one must regard it as holy or sacred. Perhaps the worshipper need not possess the concept of holiness - after all, one can be afraid without possessing the concept of the fearsome - but it seems plausible to suppose that the worshipper must represent the object of its worship as holy at some level, even if this representation need not be conceptualized.

It is not easy to say which of these properties might be essential to the notion of worship and which merely accidental. The concept of worship seems to be something of a cluster concept. Canonical instances of worship appear to involve moral, affective, aesthetic, and nominal attitudes of the kind outlined, and it is plausible to suppose that as one moves further from this core is becomes less clear whether the attitude in question still qualifies as worship. Consider, for instance, the question of whether it is possible to worship an entity that one regards as one's moral inferior. Perhaps it is. The phenomenon of devil worship certainly points in this direction, for presumably the person who worships the devil does not regard the devil as her moral superior. ${ }^{5}$ But perhaps devil 'worship' is not really worship, strictly speaking.

Another reason to wonder whether judgments of moral superiority are an essential part of worship derives from reflection on Pythagorean practices. It is sometimes said that the Pythagoreans worshipped numbers. Could this be true? Over and above the historical reasons for doubting the truth of such claims there are also philosophical reasons for doubt. ${ }^{6}$ Could a number really be a possible object of worship? Perhaps it is possible to regard numbers as mysterious, awe-inspiring, and beautiful, but it is difficult to see how one could take the kinds of moral and affective attitudes towards numbers that appear to be part-andparcel of core instances of worship. Arguably, worship in the strict sense of the term is an attitude that one can take only towards agents. Of course, animists worship rocks, trees and other natural organisms, but in doing so they regard them as agents of a kind.

Theists clearly hold that God is an appropriate object of worship, but it is less clear whether theists hold that God is the only appropriate object of worship. Call the claim that God is the uniquely appropriate object of worship the uniqueness thesis. We suspect that most monotheists would endorse the uniqueness thesis. As Exodus 20.3 puts it, the God of Abraham, Isaac and Jacob is a jealous God. Indeed, one might regard commitment to the uniqueness thesis as what 
distinguishes monotheists on the one hand from polytheists and henotheists on the other.

But do theists really endorse the uniqueness thesis? Many theists venerate saints and angels, and it seems to be extremely difficult to distinguish veneration from worship. (Perhaps this explains the ambivalence towards saints and angels within many branches of Christianity and Islam.) Also at odds with the uniqueness thesis is our willingness to refer to terrestrial relationships as involving elements of worship. Children are sometimes described as worshipping their older siblings, and fans are said to worship their heroes. What might the theist who endorses the uniqueness thesis say about such cases?

There are two sorts of strategies available to him. On the one hand, the theist might insist that these relationships typically do not, and certainly should not, involve worship in the full-blooded sense of the term. When we use the term 'worship' in describing a religious person's veneration of a saint or a child's adoration of a sibling we are using it analogically. The younger sibling's attitude towards his or her older sibling may have much in common with the devotee's attitude to God - for example, both admire and seek to emulate the object of their adulation - but the differences between them are such that we should not describe both as having the same attitude towards their respective objects. Perhaps, as Wynn suggests, 'in worship, the believer is engaging in an activity which finds no real parallel in our relations with created things' ${ }^{7}$ The theist who takes this route has an obligation to say what it is about worship that distinguishes it from similar relations - such as veneration and hero-worship - that we take to created things. As yet we have seen no satisfactory answer to this challenge.

An alternative response involves thinking of worship as admitting of degree. On this view, the theist might want to allow the worship of beings other than God, but insist that the worship of any other being must be subservient to the worship of God. The younger sibling is allowed to worship his older brother, and the religious person is allowed to worship her saint, but both instances of worship should be subservient to the worship of God.

Although some theists might be sympathetic to this revised version of the uniqueness thesis, we suspect that most theists will be reluctant to endorse it. We suspect that the majority of classical theists will insist that God ought to be the exclusive object of our worship; the worship of other beings - be they saints, angels, or humans - necessarily detracts from our worship of God. ${ }^{8}$ But as we have said, the proponent of this position owes us an account of exactly how worship differs from these other attitudes. We leave this as an open issue here.

\section{The grounds of worship}

Although accounts of the concept of God and the divine attributes rarely contain any discussion of worship, we take it that most theists hold that God is 
necessarily worthy of worship, in both de re and de dicto senses. With this in mind, we ascribe the following thesis to the theist:

Reasonableness thesis: Necessarily, it is reasonable for us to worship God.

The reasonableness thesis is not uncontroversial, but we will accept it here. ${ }^{9}$ We introduce it only to distinguish it from another thesis, the obligation thesis:

Obligation thesis: Necessarily, it is obligatory for us to worship God.

The distinction between the reasonableness and obligation theses turns simply on the distinction between what it is reasonable to do and what it is obligatory to do. As a parallel consider two positions one might adopt towards a work of art. Someone could refuse to admire Michelangelo's David despite acknowledging that the David is the sort of thing that it is reasonable to admire. Similarly, one could admit that it is reasonable to worship God without accepting that human beings - or any other beings for that matter - are obliged to worship God. It will be useful to have a term to describe the property that the obligation thesis ascribes to God. Although it is not an entirely perfect fit, we will use the term 'worshipfulness' for this property.

Despite the fact that it is stronger than the reasonableness thesis, we think that most theists would endorse the obligation thesis were they to consider it. According to Thomas V. Morris, we 'have a duty to worship God and be thankful for his benefits' ${ }^{10}$ Swinburne sounds a similar note: 'Worship is obligatory - it is the proper response of respect by man to his creator. ${ }^{11}$ Further, theists who identify sin with a failure to worship God - as many do - should be sympathetic to the obligation thesis.

It is possible that the literature on worship has not distinguished the reasonableness thesis from the obligation thesis because the latter has been thought to follow from the former. But how would such an entailment go? Does the very concept of worship entail that it is obligatory to worship any entity that it is reasonable to worship? We can see no entailment here. Certainly there does not seem to be any such entailment with respect to closely allied concepts such as love, respect, awe, and admiration. Something can be worthy of admiration, in the sense that it is reasonable to admire it, without it being the case that all creatures capable of admiring it ought to admire it. Much the same, we suggest, can be said of worship.

It is natural to assume that if the obligation thesis is true then it must have a truth-maker - there must be something in virtue of which we have an obligation to worship God. What might the basis of God's worshipfulness be? This question forms the focus of the remainder of this paper. 


\title{
Creation-based accounts
}

Some theists contend that we ought to worship God because He created us, and, indeed, continues to sustain us. According to Richard Swinburne,

\begin{abstract}
If there is a God and he has made and sustains the world and issued commands to men, men have moral obligations which they would not otherwise have. The grounds for this are as follows. Men ought to acknowledge other persons with whom they come into contact, not just ignore them - and this surely becomes a duty when those persons are our benefactors. We acknowledge people in various ways when we meet them, e.g. by shaking hands or smiling at them, and the way in which we acknowledge their presence reflects our recognition of the sort of individual they are and the kind of relation they have to us. Worship is the only response appropriate to God, the source of all being. ${ }^{12}$
\end{abstract}

In a similar vein Robert Merrihew Adams writes, 'People who worship God do not normally praise him for his moral rectitude and good judgment in creating us. They thank God for their existence as for an undeserved personal favor. ${ }^{13}$

A first objection to grounding worshipfulness in creation concerns the status of beings uncreated by God. The creation-based account would suggest that such beings have no obligations to worship God, at least if we take the account to specify the sole ground of worship. We think that this result will strike most theists as the wrong result. Presumably theists hold that any possible entity (apart from God) would have an obligation to worship God were it to be actual (and capable of worshipping God).

In response to this objection, the proponent of the creation-based account might challenge the claim that beings uncreated by God are possible. The theist might suggest that God's role as ultimate cause of all should be understood not just in terms of everything that happens to exist, but in terms of everything that could exist. On this view of things, God is the ground of all possible being.

Some theists will find this response persuasive, others may not. There is a significant current of thought within theism that recognizes uncreated objects besides God - numbers, propositions, and the like. ${ }^{14}$ Of course, abstract objects are not the sorts of things that could worship God, but the point remains that some theists allow uncreated objects (other than God) into their ontology. Such theists owes us an argument as to why uncreated objects capable of worshipping God are impossible if uncreated objects incapable of worshiping God are possible.

Even if the theist rules out the possibility of uncreated beings (capable of worshipping God), the objection from uncreated beings has some force as long as the theist allows that such entities are conceivable. The mere fact that we can conceive of beings uncreated by God allows us to ask whether such beings would have obligations to worship God. If the theist answers this question in the affirmative, then they cannot hold that worshipfulness has its sole ground in the obligations we owe our creator qua creator. 
There is a second reason to reject the creation-based accounts of worship. If creation grounds our obligation to worship God, this could only be because we ought to be grateful to God for having been created, and we could only have reason to be grateful for having been created if we are benefited by our creation. Can a person be benefited by their creation? There is good reason to think not. Arguably, an act can benefit someone only if it leaves them better off than they were, or at least, better off than they would have been had one not acted. Since we would not have been had God not created us, our creation cannot benefit us. ${ }^{15}$

Suppose that someone really believed that bringing a person into existence is - or at least can be - of benefit to the person created. Such a person would have reason to attempt to bring into existence as many people as possible, either through their own procreative powers or by encouraging others to procreate. Most of us would regard such a strategy of procreative maximization as odd if not downright perverse. This suggests that we do not really believe that bringing persons into existence constitutes a form of benevolence to the persons thus created. ${ }^{16}$

The proponent of the creation-based account of worship might accept that in the final analysis the claim that we can be benefited by being brought into existence is indefensible. Nonetheless, she might insist that it is intelligible to think of ourselves as having been benefited by having been brought into existence. And, she continues, perhaps the intelligibility of the claim suffices to ground the obligation thesis.

We grant that there is a natural sense in which it is intelligible to suppose that the creation of a person benefits them. We also grant that the intelligibility of this claim might support the reasonableness thesis: if it is reasonable to think that one has benefited from having been brought into existence, and if it is reasonable to believe that one owes one's existence to God, then it may be reasonable to worship God. But we are concerned with the obligation thesis rather than the reasonableness thesis, and the intelligibility of the claim that our creation benefits us is clearly insufficient to ground the obligation thesis.

A third objection to the creation thesis develops this theme in more detail. Whether or not it is possible to benefit a person by creating them, it is certainly plausible to suppose that not everyone is benefited by being brought into existence. Like Job, many have cursed the day of their birth, and although some such judgements might be unjustified, it is difficult to believe that everyone does well by having been created. Some individuals are born into lives of such pain and anguish that, were their parents to have deliberately created them knowing what kinds of lives they would be subject to, we would judge them guilty of callousness. If parents can be held blameworthy for bringing certain types of children into existence it is at best unclear why we cannot also hold God blameworthy. Do individuals born into utterly miserable lives have any obligation to worship God, the source of all being? One might think not. 
At this point the analysis of worship meets up with the problem of evil. Marilyn McCord Adams has argued that God has an obligation to ensure that every person's life is, on the whole, good. ${ }^{17}$ Adams grants that some individuals meet with such adversity that, if we were to consider only their terrestrial life, we would have no option but to regard their existence as being of harm to them. Adams argues that communion with God in an afterlife could make it the case that, all things considered, the lives of such people are of benefit to them. Adams's proposal provides the theist with a way of responding to the 'lives-not-worthliving' objection.

The issues raised by Adams's position are wide-ranging, and we cannot hope to deal with them adequately here. What we can note is that the considerations just adduced give the theist who wishes to ground the obligation thesis in creation additional reason to take Adams's proposal seriously. At the same time, both those who are sceptical of the notion of an afterlife and those who doubt that even communion with God could counterbalance an otherwise horrendous life will regard the problem of horrendous evils as providing additional reason to reject any attempt to ground worshipfulness in creation. ${ }^{18}$

A final problem with the creation-based account is that it runs the risk of 'domesticating' worship - that is, of presenting it as continuous with attitudes it is appropriate to take to mundane entities. If our dependence on God gives us an obligation to worship God, it ought to follow that our dependence on our parents, our friends, and family, and even our society will generate obligations to worship these individuals. The theist who emphasizes the uniqueness thesis and holds that worship has 'no real parallel in our relations with created things' will want to resist this inference. Of course, the theist can always insist that our dependence on God is qualitatively distinct from the dependence we have on terrestrial realities. God is the ultimate ground of our being, whereas our dependence on terrestrial realities is merely causal. And since our dependence on God is of a different order from our dependence on other beings, so too our response of thankfulness to God should also be of a different order.

Even if we were to accept this distinction between forms of dependence, the original worry remains: worship has, on this account, been reduced to thankfulness or gratitude. It has been emptied of its moral, aesthetic, and noumenal components. This suggests that creation-based considerations can, at best, provide only a partial account of the grounds of our putative obligation to worship God.

\section{The maximal-excellence account}

Another approach to worshipfulness appeals to God's intrinsic nature rather than His relation to us. Robert Merrihew Adams suggests that worship involves the acknowledgment, 'not just of God's benefits to us, but of [God's] 
supreme degree of intrinsic excellence'. ${ }^{19}$ In what does God's excellence consist, and what might it be about God's excellence that makes Him worthy of worship?

It is natural to conceive of divine excellence in terms of the superabundance of good-making attributes. This is the road taken by Anselmian theology, according to which God is a maximally excellent being. Call the set of properties that constitute God's maximal excellence ' $M$ ', and call those properties included within M,'M-properties'. Could M-properties - either singly or in combination - ground worshipfulness?

Theists typically include perfect goodness, knowledge, power, and presence within $\mathrm{M}$. These properties seem to be neither individually nor jointly sufficient to ground worshipfulness. We can imagine a being who is more knowledgeable, more powerful, and more 'present' than us, and although such properties might make it reasonable to worship the being in question, they do not appear to establish the rights of that person to demand worship from us. Worshipping God for His power or His knowledge seems to smack of fascism. The idea that moral perfection obligates worship is less objectionable, but not unproblematic. Most of us recognize various other persons as our moral superiors, yet few of us suppose that we have obligations to worship such persons. Perhaps we ought to recognize their moral superiority and aspire to emulate their behaviour, but these attitudes seem to fall short of worship.

What other properties might be included within $\mathrm{M}$ ? It is sometimes suggested that God has a greater degree of being (or reality) than the created order. We are not particularly sympathetic to this view, but we will waive such worries here. Could the fact that God has more reality than we do justify our having an obligation to worship Him? Again, we find it hard to see how an argument for this claim might proceed.

In our view, the most attractive maximal excellence account of worship identifies the ground of God's worshipfulness with a property not normally included in M: holiness. Worship, on this view, is the appropriate response to holiness. It is not completely clear how God's holiness is generally conceived, but we suspect that most theists regard it as primitive. That is to say, even if God's holiness necessarily presupposes certain other properties (such as moral perfection), His holiness does not supervene on His possession of those properties. Nonetheless, it is plausible to suppose that holiness is a necessary component of $\mathrm{M}$, insofar as being holy is a great-making property (for persons, at least).

An obvious objection to the attempt to ground worship on holiness is that holiness is itself a rather mysterious notion. To use J. L. Mackie's term, holiness seems to be queer. Of course, queerness is in the eye of the beholder, and the theist will no doubt resist any suggestion that there might be something ontologically suspect about holiness. 
A more compelling problem for theists is the fact that holiness appears to be a property that God shares - or at least could share - with other beings. Certain individuals are described as holy, and there are strains of thought within many religious traditions according to which the faithful become holy. This suggests that holiness per se cannot ground worship, for if it did then we would have obligations to worship other holy beings, and the uniqueness thesis would be imperilled.

Another problem with the maximal-excellence account concerns the possibility of multiple maximally excellent beings. It seems possible for a world to contain two beings, each of whom instantiates those properties included within M. Call one of the two beings 'God' and the other 'God*'. (Here, we are using 'God' and 'God*' as proper names.) If worshipfulness supervenes on the possession of M-properties then we would have obligations to worship both God and God*. (Indeed, God and God* would have obligations to worship each other.) This result is also at odds with the uniqueness thesis.

In response to this objection theists might reject the idea that a being other than God could be maximally excellent. They might argue that the notion of a world containing two maximally excellent beings contains a subtle contradiction. For the record, we cannot see any contradictions in the proposal, but contradictions can be difficult to spot, and perhaps there is something that we are missing. ${ }^{20}$ The crucial question here is not whether God* is logically possible - or, if it amounts to something else, whether the notion of God* is conceptually coherent - but whether the theist would acknowledge that it would be obligatory to worship God*, if, per impossibile, God* were actual. If the theist responds in the negative - as we suspect many theists will - then this casts doubt on the notion that worshipfulness is grounded in God's intrinsic excellence. Of course, the theist might not answer this question in the negative - they might hold that God* ought to be worshipped. The theist might restrict the uniqueness thesis to worlds in which God is the only maximally excellent being. We see here the dialogue between accounts of the objects of worship and accounts of the grounds of worship.

We conclude this section by considering a variant on the maximal-excellence theme. In Finite and Infinite Goods, Robert Merrihew Adams suggests that God is not merely good but is identical with perfect Goodness. We are not sure that Adams's suggestion is coherent - could a concrete particular also be a property? - but we will grant it for the sake of argument. Even so, Adams's identification of God with Goodness seems unable to ground worship. Why ought we to worship Goodness? We certainly ought to recognize the goodness of good things, but it does not follow from this that we ought to worship Goodness itself.

At this point, one might claim that although neither God's creation of us nor His maximal excellence individually warrants worship the combination of them does. But if God is already maximally excellent then His creation of 
us should not add anything to His perfection. And if that is right, then it is hard to see why only a maximally excellent creator, but not a maximally excellent being simpliciter, ought to be worshipped. Conversely, if God's creation is essential to His perfection, then His creation should be subsumed by His maximal excellence. Either way, it is difficult to see how the combination of the two proposals could ground worshipfulness if neither is individually sufficient to ground it.

\section{The prudential-reasons account}

A third approach to worshipfulness looks to prudential reason in order to ground our obligations to worship God. There are various ways in which such an approach might be developed. Consider first the 'big-stick strategy'. Theists of a certain stripe respond to the question 'Why should I worship God?' by pointing out that the failure to worship God is a sin and sin is punishable by death. This prudential-reasons account has little philosophical appeal, for it leaves the connection between worship and our wellbeing completely mysterious. We want an account of worship in virtue of which God is justified in punishing us for not worshipping Him.

A more appealing prudential-reasons approach conceives of our obligations to worship God on the model of our obligations to eat well, exercise, and develop our rational and moral faculties. According to most theists, we are designed to worship God, and our true fulfilment and happiness is found only in such an activity. As Augustine put it in his Confessions, our hearts are restless until they find their rest in God. Perhaps it is this fact that forms the basis of our obligation to worship God.

Do human beings need to worship something in order to achieve fulfilment? Perhaps. Certainly the ubiquity of religion suggests that the psychological roots of worship go very deep. But must the object of our worship be God? At this point the prudential-reasons account comes up short. The account may be able to establish that we ought to worship something or other, but it seems unable to establish that we ought to worship God.

There is also something deeply unsatisfying about the agent-centred approach taken by the prudential-reasons account. It smacks of the 'one thought too many' problem that afflicts certain moral theories. Even if it is true that we would be better off worshiping God, authentic worship should not be motivated by selfinterest. Consider an analogy. Suppose that I've offended Sarah and I feel guilty about it. Even though it may be true that I will feel better if I apologize to her, my apology should be motivated by my desire to repair my relationship with Sarah, not by my desire to feel better about myself. Similarly, even if it is true that worshipping God brings with it prudential rewards, it should not be motivated by the prospect of such rewards. 


\section{Groundless worship?}

In light of the difficulties theists face in finding an adequate ground for worship, one might wonder whether worship has grounds. Perhaps God's worshipfulness is groundless. Perhaps we have obligations to worship God even though God has no property, either intrinsic or relational, in virtue of which we have obligations to worship Him. Call this the brute-fact account. Surely some of God's properties are brute. Why couldn't God's worshipfulness not be brute?

One might object that if the brute-fact approach were correct then God's worshipfulness would be contingent, and if worshipfulness were contingent then there would be a possible world in which God would exist but we would not have obligations to worship Him - which is at odds with the necessity thesis.

Now, why might the bruteness of God's being worshipful entail that God has this property only contingently? After all, surely a brute property can also be a necessary property? Well, we are entering some tricky terrain here, but we suggest that they only brute properties that an entity has necessarily are those that follow from the nature of the entity in question. Where a brute property is not bound up with an entity's nature it seems plausible to regard it as contingent.

For example, consider the property of having developed from a particular pair of gametes. This property appears to be brute. Is it also a contingent property? Could a person have developed from a set of gametes other than those from which he or she actually developed? Not if essentialist accounts of our origins are correct. ${ }^{21}$ Essential accounts hold that the property of having developed from a particular pair of gametes is both brute and necessary. And such accounts have some plausibility, for essentialism about our origins appears to be in accord with the kinds of things we are.

But let us consider another situation in which a putatively basic property has been said to be necessary. ${ }^{22}$ Consider, she may say, the property of being depraved - that is, of committing some sin in one's life. Plantinga has suggested that this property, which is presumably brute, is an essential property of certain people, and that there is no possible world in which such people exist and fail to commit at least one wrong act. ${ }^{23}$ We suggest that Plantinga's proposal is implausible, for it involves regarding a brute property as necessary even though the property in question seems not to follow from the nature of the entity concerned. After all, there seems to be nothing internal to the concept of being a human being that makes it the case that a human being must commit at least one sin in its life. (And if there were such a claim, then accounts of the incarnation would be in trouble!). In order to get around this problem Plantinga states that the transworld depravity might be included in the essence of particular creatures, but this move seems to be completely unmotivated. We conclude that there is good reason to think that brute properties that do not follow from the nature of the entity in question will be contingent. 
Where does this leave the worshipfulness of God? Well, if what we have said thus far is on the right track, we need to ask what the nature of God is. Might worshipfulness follow from the kind of thing that God is? At this point we hit an impasse of sorts, for even if God has a nature - and it is by no means uncontroversial that He does - there is little agreement between theists about how God's nature is to be understood. Perhaps all that can be said here is that God's worshipfulness would appear to be contingent to the extent that it fails to follow from properties that are essential to His nature. Of course, theists will differ about which, if any, properties are essential to God's nature.

A second reason for rejecting the brute-fact account is that it problematizes the epistemology of worship. Intuitively, the judgement that a particular object ought to be worshipped will be based on the evidence that the object in question instantiates those properties that ground worshipfulness. So, if worshipfulness is grounded in our creation (for example), then we need to look only to God's creative activity in order to determine whether or not we ought to follow Him. But if worshipfulness is primitive, then it is unclear how we might go about determining whether or not to worship God. In short, the brute-fact approach complicates the epistemology of worship. If worshipfulness does not follow from the essence of God then we need some additional reason to think that God has the property of being worshipful.

A final problem with the brute-fact proposal is simply that it seems to us that the question of why we have an obligation to worship God deserves a substantive answer. If I have an obligation to praise someone, then that person must have a property that makes it the case that I ought to praise her. Similarly, if I have an obligation to thank someone, then that person must have a property that grounds my obligations. Of course, there are some obligations - such as the obligations children have to their parents - the grounds of which it is notoriously difficult to specify. But even when we confront such difficult cases, few are inclined to call into question the claim that obligations must be underwritten by real properties or relations.

When the grounds of a putative obligation elude identification it is natural for the obligation itself to be called into question. One might argue that the lesson to be learnt from the failure to find the grounds of worship is not that worshipfulness is brute, but that there is no such property. Here we have the makings of an argument against the existence of God, for God is typically regarded as demanding of our worship. Of course, any such argument would have to be developed with care. Sometimes it is reasonable to think that $p$ is the case even when one has no idea what might make it the case that $p$. The theist might argue such a description applies to the necessity thesis: we know what it is true, but we do not know why it is true. It is always possible for the theist to insist that although Godworshipfulness is grounded, its grounds are hidden. Nonetheless, insofar as it is reasonable to think that the grounds of worshipfulness would be scrutable to us, 
our inability to determine what those grounds could be gives us reason to call into question the claim that we have obligations to worship God.

\section{Conclusion}

Theists of many stripes hold that it is obligatory for us to worship God. We have examined four accounts of why it might be that we have obligations to worship God, and have argued that none is successful. We do not claim that the considerations adduced here demonstrate that the necessity thesis is false, but we do think that they problematize it. At the very least, we hope that they prompt philosophers of religion to ponder the nature and basis of worship in more detail than they have to date. Theists who hold that the necessity thesis is internal to the very concept of God have especial reason to address our concerns, because for them, our argument threatens not only the worshipfulness of God but His very existence. $^{24}$

\section{Notes}

1. This is not to say that there is no philosophical analysis of the notion of worship. For a variety of perspectives on worship see R. Otto The Idea of the Holy (Oxford: Oxford University Press, 1958, 2nd edition); N. Smart The Concept of Worship (London: Macmillan, 1972); E. Underhill Worship (New York: Harper and Row, 1936); and Mark Wynn God and Goodness (London: Routledge, 1999), especially ch. 6.

2. R. M. Adams Finite and Infinite Goods (Oxford: Oxford University Press, 1999), 193.

3. Wynn God and Goodness, 151-152.

4. Otto The Idea of the Holy.

5. We thank an anonymous referee for this point.

6. See G. S. Kirk, J. E. Raven, and M. Schofield The Presocratic Philosophers (2nd edn) (Cambridge: Cambridge University Press, 1983), and J. Barnes The Presocratic Philosophers (New York and London: Routledge, 1979) for historical reasons to doubt the claim that the claim that the Pythagoreans worshipped numbers.

7. Wynn God and Goodness, 145.

8. One might assume a 'fixed-quantity' account of worship: we have a limited amount of worship to give, and apportioning any of it to beings other than God diminishes the amount we can give to God. A related view is the thesis that worship is simple and cannot be split into parts. On this view, at any one point in time one can worship only one entity, albeit, perhaps, to a greater or lesser degree. We leave these options open here.

9. For an argument against the reasonableness thesis see J. Rachels 'God and human attitudes', Religious Studies, 7 (1971), 325-337.

10. T. V. Morris 'Duty and divine goodness', American Philosophical Quarterly, 21 (1984), 261-268. Reprinted in his Anselmian Explorations: Essays in Philosophical Theology (Notre Dame IN: University of Notre Dame, 1987), 26.

11. R. Swinburne, Faith and Reason (Oxford: Clarendon Press, 1981), 126.

12. Ibid., 79. For a critical analysis of Swinburne's creation-based account from a theological point of view see ch. 6 of Wynn God and Goodness.

13. R. M. Adams 'Must God create the best?', Philosophical Review, 81 (1972), 317-332, 324.

14. See M. Davidson 'A demonstration against theistic activism', Religious Studies, 35, (1999), 277-290; idem 'God and other necessary beings', in Edward N. Zalta (ed.) The Stanford Encyclopedia of Philosophy (Summer 2005 edn), (http://plato.stanford.edu/archives/sum2005/entries/god-necessary-being/), and S. A. Davison 'Could abstract objects depend upon God?', Religious Studies, 27 (1991), 485-497. For 
contrary views see T. V. Morris and C. Menzel 'Absolute creation', American Philosophical Quarterly, 23 (1986), 53-362, and C. Menzel 'Theism, Platonism, and the metaphysics of mathematics', Faith and Philosophy, 4 (1987), 365-382.

15. D. Heyd Genethics: Moral Issues in the Creation of People (Berkeley CA: University of California Press, 1992).

16. We grant that the considerations provided in the text are not decisive. On the other side of the equation is the thought that an individual can be harmed by being brought into existence. Intuitively, there ought to be symmetry between harms and benefits, such that it is possible to harm someone by bringing them into existence, if and only if it is possible to benefit someone by bringing them into existence. So, if we are unwilling to give up the claim that it is possible to harm someone by creating them, then perhaps we should accept that it is possible to benefit someone by creating them.

17. M. McCord Adams 'Horrendous evils and the goodness of God', Proceedings of the Aristotelian Society (supplementary volume), 63 (1999), 299-310.

18. The theist might respond that it is impossible to harm someone by bringing them into existence - not because the goods of life necessarily outweigh the evils of life, but because of logical problems involved in comparing existence and nonexistence. But if the theist takes this line then s/he is not entitled to argue that our obligation to worship God is grounded in the benefits we accrue from having been created, for that claim would itself demand comparing the benefits of existence with those of nonexistence.

19. R. M. Adams 'Finite and infinite goods', 14.

20. Perhaps < being the ground of every other being > is a property that ought to be included in M, in which case a world could contain only a single M-type being.

21. See S. Kripke Naming and Necessity (Oxford: Blackwell, 1980).

22. We thank an anonymous referee for drawing this line of argument to our attention.

23. A. Plantinga God, Freedom and Evil (Grand Rapids MI: Eerdmans, 1977).

24. We thank two anonymous referees for their very useful comments on a previous draft of this paper. 